\title{
СТИМУЛИРУЮЩИЕ СВОЙСТВА ПРЕПАРАТА КРЕЗАЦИНА ПРИ ВЫРАЩИВАНИИ АМАРАНТА (Amaranthus L.)
}

\section{Л.Л. КИРИЛЛОВА ${ }^{1}$, Г.Н. НАЗАРОВА ${ }^{2}$, А.М. ПЕШКОВА ${ }^{1}$, Е.П. ИВАНОВА ${ }^{2}$}

Крезацин - адаптоген человека и животных на основе трис(2-оксиэтил)аммоний ортокрезоксиацетата, который в России применяют как стимулятор роста и продуктивности сельскохозяйственных культур: пшеницы, овса, шпината, картофеля и др. В других странах в таком качестве крезацин не используют. Отсутствуют сведения о его применении при культивировании пищевого амаранта (Amaranthus L.) - источника высококачественного белка и иных полезных веществ. В настоящем исследовании мы впервые получили данные о действии предпосевной обработки крезацином на всхожесть семян, развитие и биометрические параметры растений у пищевого амаранта в разные фазы онтогенеза, а также на его продуктивность и питательность. Установлена способность крезацина повышать активность нитратредуктазы, влиять на содержание нитритного азота $\mathrm{N}-\mathrm{NO}_{2}$ на ранних стадиях вегетации, увеличивать скорость транспорта электронов в цепи их переноса и синтеза АТФ. Целью работы была оценка эффективности влияния растворов крезацина в разной концентрации на всхожесть семян, качество всходов, ростовые параметры растений пищевого амаранта, активность аппаратов фотосинтеза и ассимиляции азота. Семена амаранта Amaranthus caudatus L. (сортообразец K173) и Amaranthus cruenthus L. (сортообразец K185) обрабатывали замачиванием на 1 сут в растворах крезацина разной концентрации (опыт) или в дистиллированной воде (контроль). Затем их высушивали при комнатной температуре в слабом токе воздуха и использовали в экспериментах. В опыте 1 семена обрабатывали водными растворами препарата в концентрациях от $10^{-10}$ до $10^{-5} \mathrm{M}$, проращивали на влажной фильтровальной бумаге в чашках Петри в течение 72 ч при $24{ }^{\circ} \mathrm{C}$ и подсчитывали долю проросших семян. В опыте 2 изучали влияние крезацина на ростовые и физиолого-биохимические параметры растений. Семена обрабатывали $10^{-7} \mathrm{M}$ раствором крезацина, проращивали, откалиброванные проростки пересаживали в кюветы с песком. Биометрические показатели учитывали каждые 15 сут до сбора урожая (120-е сут), о продуктивности судили по приросту зеленой массы. В листьях 45-суточных растений определяли содержание хлорофилла. Фотохимическую активность изолированных хлоропластов оценивали по скорости электронного транспорта и фотофосфорилирования. В листьях растений с 15-х по 45-е сут измеряли активность нитратредуктазы, содержание $\mathrm{N}-\mathrm{NO}_{2}$ и общего белка. Чистую продуктивность фотосинтеза (ЧПФ) за период с 45-х по 60-е сут рассчитывали по методу А.А. Ничипоровича. В опыте 1 у обоих исследованных сортообразцов установлено изменение всхожести семян в зависимости от концентрации препарата. При концентрации $10^{-8}$ М наблюдали достоверное повышение всхожести семян амаранта на $10 \%(P=0,95)$ по сравнению с контролем, при $10^{-7} \mathrm{M}-$ на $25 \%$ (максимальный стимулирующий эффект), а при $10^{-5}$ М всхожесть падала на $22 \%$. При прочих концентрациях препарата достоверный эффект отсутствовал. В опыте 2 масса всходов из обработанных семян обоих сортообразцов на стадии скрытого роста вдвое превышала контроль, а длина главного корня - в 1,6 раза. На более поздних этапах развития в зависимости от фазы онтогенеза зеленая масса растений в опыте превышала контроль в 1,3-2,0 раза. На высоту растений обработка не влияла. ЧПФ листьев после обработки превышала контроль на 26 \% (Р = 0,95). При этом содержание хлорофилла в листьях не изменялось, скорость транспорта электронов в хлоропластах увеличивалась более чем на $30 \%$, а фотофосфорилирования - на $60 \%$. Активность нитратредуктазы в листьях на 45-е сут повышалась почти на $60 \%$, содержание общего белка на $20 \%$, нитритного азота $\mathrm{N}-\mathrm{NO}_{2}$ - на $16 \%(\mathrm{P}=0,95)$. Таким образом, установлено стимулирующее действие крезацина на семена и растения амаранта, процессы фотосинтеза и синтеза белка, приводящие к повышению продуктивности и пищевой ценности растений.

Ключевые слова: трис(2-оксиэтил)аммоний орто-крезоксиацетат, крезацин, амарант, всхожесть семян, регуляция роста растений, фотофосфорилирование, транспорт электронов, содержание белка, нитратредуктаза, продуктивность, пищевая ценность.

В 1970-х годах группа ученых под руководством М.Г. Воронкова синтезировала биологически активное химическое соединение трис(2-оксиэтил)аммоний орто-крезоксиацетат, или крезацин. Высокоочищенный крезацин под названием трекрезан первоначально предназначался для использования в медицине как адаптоген и иммуностимулятор, а также в животноводстве и ветеринарии (1). Позднее было установлено, что он ока- 
зывает стимулирующее действие не только на животные организмы, но и на растения, а в почве подвергается естественной деградации с образованием воды и углекислого газа (2).

В настоящее время крезацин (триэтаноламмониевая соль ортокрезоксиуксусной кислоты) и в составе препаратов Крезацин, Энергия-М, КРП, ТАБ, Мивал внесен в Государственный каталог (3) пестицидов и агрохимикатов, разрешенных к применению на территории Российской Федерации, в качестве стимулятора роста многих сельскохозяйственных культур (пшеницы, кукурузы, овса, капусты, шпината, картофеля и др.). Подробно описаны способы обработки, а также эффекты от применения крезацина: повышение всхожести семян, усиление ростовых процессов, увеличение урожайности, улучшение качества продукции, повышение устойчивости к неблагоприятным факторам среды. Однако мы не обнаружили сведений о влиянии крезацина на светозависимые процессы фотосинтеза, а также на отдельные компоненты системы усвоения азота и синтеза белка в растениях. Также и в отечественной, и в зарубежной литературе отсутствуют данные о применении крезацина при культивировании растений рода Амарант (Amaranthus L.).

Представители рода Амарант, или Щирица, насчитывающего более 100 видов, уникальны по своим свойствам. На протяжении тысячелетий они используются на континентах Южной Америки, Азии и Африки как пищевые, лекарственные, кормовые, декоративные культуры $(4,5)$. При том, что съедобны все части растений (6), их подразделяют на псевдозерновые и листовые (овощные) формы $(7,8)$. Высокая пищевая и лекарственная ценность амаранта научно обоснована многочисленными современными исследованиями химического состава органов и тканей этих растений. Все части растений амаранта отличаются высоким содержанием белка (4-7), а семена (зерно) превосходят по его количеству и качеству даже бобовые культуры (9-11). Белок амаранта, обогащенный лизином и другими незаменимыми аминокислотами $(10,11)$, близок животному белку по пищевой ценности, и превосходит его по усвояемости (10-12).

Помимо этого, представители рода служат богатым источником минеральных элементов - железа, меди, цинка, селена, фосфора, кальция $(12,13)$. В них обнаружено повышенное содержание витаминов C $(11,15)$, A, Е, группы В (11-15) и другие полезные соединения - флавоноиды, антоцианы, каротиноиды, рутин (8-11), сквален (16) и антиоксиданты, обладающие противоопухолевыми, антибактериальными и противовоспалительными свойствами $(6,14,17)$. Употребление экстрактов амаранта, листьев, семян, масла или шрота как в составе блюд, так и в качестве лекарства помогает в профилактике и лечении заболеваний сердечно-сосудистой (18) и пищеварительной систем, сахарного диабета, ожирения (13-17). Растения амаранта используют для приготовления продуктов детского и диетического питания $(14,17)$.

Благодаря полезным свойствам, эта южная культура приобретает популярность во многих странах мира $(4,5,19)$, однако ее интродукция может вызвать затруднения как из-за условий окружающей среды $(19,20)$, так и в результате особенностей физиологии культуры $(4,5,7-10)$. У амаранта очень мелкие семена, которые прорастают неравномерно, и маленькие всходы с тонкими стеблями, которые через 5-7 сут после прорастания входят в состояние скрытого роста на 2-3 нед. В этот период активно развивается только корневая система, а надземная часть останавливается в росте. Такие проростки сильно страдают от ветра, недостатка влаги и све- 
та, легко забиваются сорняками и погибают $(7,21)$. В странах Европы и центральной России развитие растений амаранта замедлено (19-21), поскольку для этой южной культуры оптимальны условия более высокой инсоляции и температуры.

Представляется необходимым улучшение качества посевного материала, укрепление габитуса всходов за счет ускорения развития на стадии скрытого роста и повышения устойчивости к факторам окружающей среды, а также повышение продуктивности взрослых растений и увеличение их пищевой ценности. Для этого широко используют предпосевную обработку семян различными стимуляторами $(20,21)$. В контексте последних европейских правил, рекомендующих ограничить применение пестицидов (22), особенно привлекательны экологически безопасные стимуляторы, улучшающие ростовые и адаптивные качества растений. В предыдущих работах мы показали высокую эффективность использования при выращивании Amaranthus caudatus (сортообразец К173) и A. cruenthus (сортообразец К185) ряда препаратов: 2-(4-гидрокси)фенил этанола - экзометаболита пурпурной бактерии с цитокининовой активностью (23), гибберсиба - гиббереллинового препарата на основе продуктов жизнедеятельности грибной культуры (24), пара-аминобензойной кислоты - компонента фолатов (25).

В литературе описаны свойства крезацина, которые особенно важны для культуры амаранта. Установлено, что крезацин способствует повышению всхожести семян овса (26), увеличению массы и высоты растений картофеля (27), повышению чистой продуктивности фотосинтеза озимой пшеницы (28) и содержания общего белка в зерне яровой пшеницы (29), а также количества хлорофилла в листьях вайды красильной (30). Особым преимуществом крезацина при культивировании листового амаранта может быть его способность вызывать значительное накопление зеленой массы, показанная на растениях картофеля и шпината $(31,27)$.

В настоящем исследовании мы впервые получили данные о действии предпосевной обработки крезацином на всхожесть семян, развитие и биометрические параметры растений пищевого амаранта в зависимости от фазы онтогенеза, а также на их продуктивность и питательность. Установлены ранее не описанные свойства крезацина: способность повышать активность нитратредуктазы, влиять на содержание нитрита на ранних стадиях вегетации, увеличивать скорость транспорта электронов в цепи их переноса и синтеза АТФ.

Целью работы была оценка эффективности влияния растворов крезацина в разной концентрации на всхожесть семян, качество всходов, ростовые параметры растений пищевого амаранта, активность аппаратов фотосинтеза и ассимиляции азота.

Методика. Семена амаранта Amaranthus caudatus L. (сортообразец K173) и Amaranthus cruenthus L. (сортообразец K185) со всхожестью $70 \%$ были предоставлены Всероссийским НИИ селекции и семеноводства овощных культур (Московская обл.). Крезацин использовали в виде кристаллического порошка с содержанием действующего вещества 95 \% (ОOО «Флора-Си», Россия). Семена обрабатывали замачиванием на 1 сут в дистиллированной воде (контроль) или в растворах крезацина разной концентрации (опыт). Затем их высушивали при комнатной температуре в слабом токе воздуха и использовали в экспериментах.

При определении влияния крезацина на всхожесть семян (опыт 1) для замачивания использовали водные растворы препарата в концентра- 
циях от $10^{-10}$ до $10^{-5} \mathrm{M}$. После проращивания на влажной фильтровальной бумаге в чашках Петри в течение 72 ч при $24{ }^{\circ} \mathrm{C}$ подсчитывали долю проросших семян.

Для оценки влияния крезацина на ростовые и физиолого-биохимические параметры растений (опыт 2) при обработке семян использовали $10^{-7}$ М раствор крезацина, после проращивания откалиброванные проростки пересаживали в кюветы с песком. На один вариант эксперимента приходилось по 3 кюветы, в одной кювете было по 10 проростков. Кюветы помещали в температурную камеру для роста растений LCC-1000MP Daihan Labtech («Daihan Labtech Co., Ltd», Южная Корея) со следующими параметрами: освещенность - 150 Вт/м ${ }^{2}$, температура $-24{ }^{\circ} \mathrm{C}, 14$-часовой фотопериод. Полив проводили 1 раз в сутки питательной средой Кноппа. Биометрические показатели учитывали каждые 15 сут до сбора урожая (120-е сут), о продуктивности судили по приросту зеленой массы. В листьях 45-суточных растений определяли содержание хлорофилла (32). Фотохимическую активность изолированных хлоропластов (33) оценивали по скорости электронного транспорта (34) и фотофосфорилирования (35). В листьях растений с 15-х по 45-е сут измеряли активность нитратредуктазы (НР), содержание нитритного азота (36) и общего белка (37). Чистую продуктивность фотосинтеза (ЧПФ) за период с 45-х по 60-е сут рассчитывали по методу А.А. Ничипоровича (38).

В статье представлены результаты одного типичного эксперимента из пяти. Биометрические параметры определяли у 30 растений. Повторность биохимических анализов 3-кратная.

Статистическую обработку проводили в программе Microsoft Excel. В таблицах и на рисунках приведены средние арифметические значения $(M)$ и стандартные ошибки средних $( \pm \mathrm{SEM})$. Достоверность различий оценивали по $t$-критерию Стьюдента при $\mathrm{P}=0,95$.

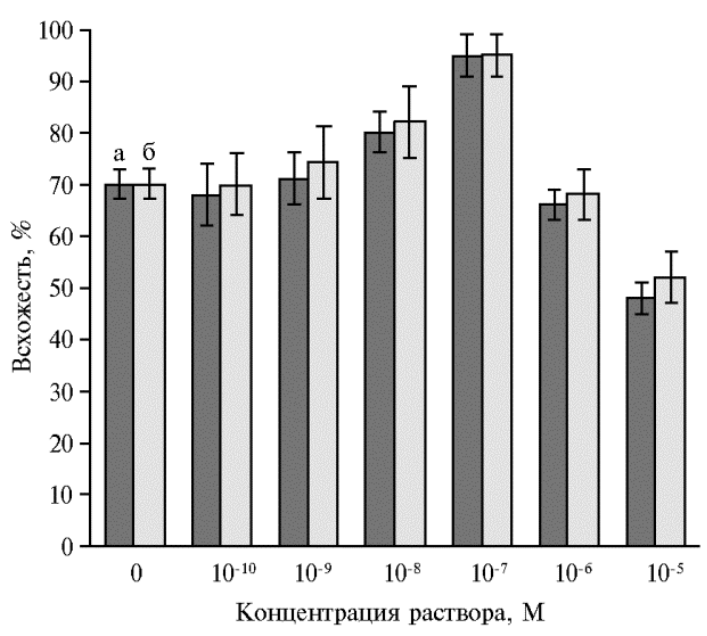

Рис. 1. Всхожесть семян амаранта Amaranthus caudatus L. (сортообразец K173) (а) и Amaranthus cruenthus L. (сортообразец K185) (б) после обработки водными растворами крезацина в разной концентрации (лабораторный опыт).

В опыте 2 использовали $10^{-7}$ М раствор крезацина, поскольку эта концентрация оказалась оптимальной для всхожести семян. Масса надземной части растений обоих сортообразцов на протяжении всей жизни препосевной обработке семян амаранта водными растворами крезацина всхожесть зависела от концентрации препарата, причем эффект оказался одинаковым для обоих исследованных сортообразцов (рис. 1). При концентрации $10^{-8} \mathrm{M}$ всхожесть достоверно $(\mathrm{P}=0,95)$ повышалась на $10 \%$ по сравнению с контролем, при $10^{-7}$ М наблюдался максимальный стимулирующий эффект для каждого сортообразца - повышение всхожести на $25 \%(\mathrm{P}=0,95)$, а при $10^{-5} \mathrm{M}$ показатель падал на $22 \%(P=0,95)$. При прочих концентрациях препарата достоверный эффект отсутствовал.

Результаты. При пред- 
вышала контроль более чем на $20 \%$ (рис. 2), при этом эффект препарата был связан с фазами онтогенеза. Так, 15- и 30-суточные проростки, находящиеся на стадии скрытого роста, превосходили контрольные по массе соответственно на $60 \%$ и $100 \%(\mathrm{P}=0,95)$ (см. рис. 2). При этом у обоих сортообразцов наблюдалось увеличение длины главного корня 15-суточных проростков в среднем на $60 \%(\mathrm{P}=0,95)$.

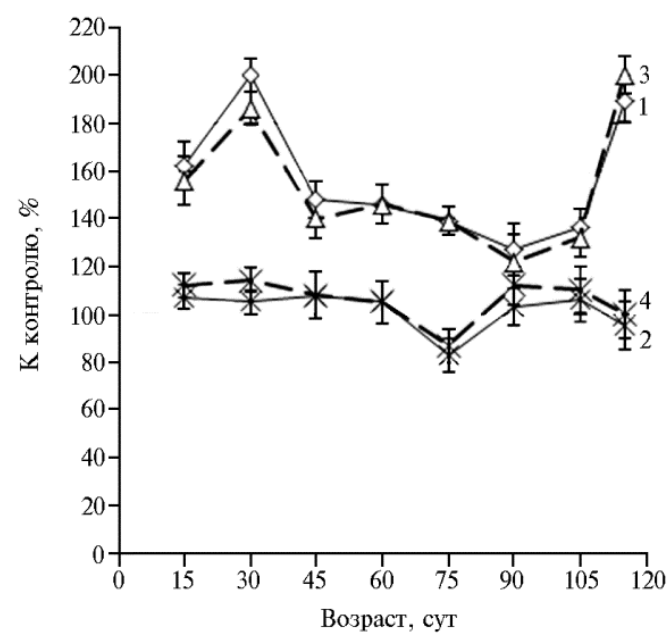

Рис. 2. Прирост массы $(1,3)$ и высоты $(2,4)$ растений амаранта Amaranthus caudatus L. (сортообразец K173) $(1,2)$ и Amaranthus cruenthus L. (copтообразец K185) $(3,4)$ при предпосевной обработке семян $10^{-7} \mathrm{M}$ раствором крезацина в зависимости от возраста (лабораторный опыт).

В период активной вегетации (45-60-е сут) накопление зеленой массы снижалось в сравнении с предыдущей фазой, но оставалось в среднем на $45 \%$ выше, чем в контроле. При этом отдельно масса листьев у К173 на 60-е сут была болыше, чем в контроле, на $46 \%$, у К185 - на $52 \%$ $(\mathrm{P}=0,95)$. На 90-е сут накопление массы надземной части снижалось, но все же достоверно $(\mathrm{P}=0,95)$ превышало контроль на $27 \%$. На 120 -е сут масса надземной части растений, выращенных из обработанных семян, снова почти вдвое превышала контроль.

Предпосевная обработка крезацином не влияла на рост растений амаранта в высоту на протяжении их жизни, за исключением 75-х сут, когда экспериментальные растения отставали от контроля почти на $20 \%(\mathrm{P}=0,95)$.

При исследовании световых реакций фотосинтеза у 45-суточных растений К173 было выявлено повышение скорости транспорта электронов в электрон-транспортной цепи изолированных хлоропластов и фотосинтетического фосфорилирования (табл. 1). Содержание хлорофилла в листьях достоверно не изменялось. ЧПФ листьев, вычисленная

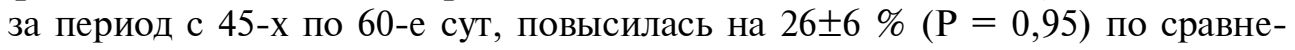
нию с контролем.

1. Содержание хлорофилла, скорость транспорта электронов и фотофосфорилирования в хлоропластах из листьев 45-суточных растений амаранта $\mathrm{Ama}$ ranthus caudatus L. (сортообразец K 173) при предпосевной обработке семян 10-7 М раствором крезацина ( $\pm \pm \mathrm{SEM}$, лабораторный опыт)

\begin{tabular}{|c|c|c|c|c|c|}
\hline \multirow{3}{*}{ Вариант } & \multirow{2}{*}{$\begin{array}{l}\text { Содержание хлоро- } \\
\text { филла в листьях }\end{array}$} & \multicolumn{4}{|c|}{ Скорость } \\
\hline & & \multicolumn{2}{|c|}{ транспорта электронов } & \multicolumn{2}{|c|}{ фотофосфорилирования } \\
\hline & \begin{tabular}{|l|l|} 
мг/г сухой & К контролю, \\
массы & $\%$ \\
\end{tabular} & мкмоль $\mathrm{K}_{3}\left[\mathrm{Fe}(\mathrm{CN})_{6}\right]$ & $\begin{array}{l}\text { К контролю, } \\
\%\end{array}$ & мкмоль АТФ & $\begin{array}{l}\text { К контролю, } \\
\%\end{array}$ \\
\hline Контроль & $100,0 \pm 2,0$ & $110,4 \pm 7,7$ & $100,0 \pm 7,0$ & $112,0 \pm 4,3$ & $100,0 \pm 3,8$ \\
\hline Опыт & $106,1 \pm 9,1$ & $148,9 \pm 7,0$ & $134,9 \pm 6,1$ & $184,5 \pm 9,4$ & $164,7 \pm 4,5$ \\
\hline
\end{tabular}

Влияние предпосевной обработки крезацином на элементы системы ассимиляции азота изучали на ранних этапах вегетации (15-45-е сут) растений амаранта К173. По всем параметрам выявили эффект, степень проявления которого была обусловлена онтогенетически (табл. 2). Так, активность нитратредуктазы в 1,5 раза возрастала только на 45-е сут, ко- 
личество общего белка в листьях превышало контроль в среднем на 20$30 \%$, а содержание нитрита колебалось в продолжение всего этого периода развития $(\mathrm{P}=0,95)$.

2. Показатели системы усвоения азота (к контролю, \%) в листьях у растений амаранта Amaranthus caudatus L. (сортообразец K173) при предпосевной об-

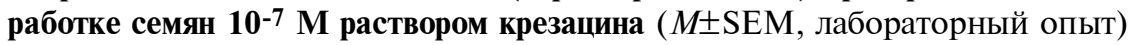

\begin{tabular}{l|c|c|c}
\hline Возраст растений, сут & Активность нитратредуктазы & Нитритный азот $\mathrm{N}^{-\mathrm{NO}_{2}}$ & Общий белок \\
\hline 15 & $109 \pm 5$ & $135 \pm 2$ & $132 \pm 9$ \\
30 & $102 \pm 6$ & $106 \pm 4$ & $129 \pm 4$ \\
45 & $158 \pm 7$ & $116 \pm 4$ & $120 \pm 5$ \\
\hline
\end{tabular}

Таким образом, мы установили зависимость всхожести семян амаранта от дозы крезацина, которым их обрабатывали, в широком диапазоне $\left(10^{-10}-10^{-5} \mathrm{M}\right)$ низких концентраций препарата. У растительных объектов такая зависимость эффекта химического агента от дозы характерна для фитогормонов (39). Они проявляют биологическую активность в крайне низких дозах, причем в узком диапазоне концентраций действуют как стимуляторы, а при его превышении - как ингибиторы. Благодаря такому свойству крезацина, установленному нами впервые, можно предполагать наличие у него гормонподобных свойств. Отметим, что некоторые авторы сравнивают проявление активности крезацина с действием ауксинов и гиббереллинов $(2,28)$. Однако более обоснованной нам представляется гипотеза о наличии неких элиситорных свойств у множества малых молекул, обладающих биологической активностью, к которым можно отнести и крезацин (40). Это предположение мы поддерживали ранее при исследовании свойств п-аминобензойной кислоты и 4-гидроксифенэтилового спирта $(27,29)$.

Мы не обнаружили влияния крезацина на рост растений амаранта в высоту, хотя такое свойство было описано $(30,35)$, за исключением 75-х сут (стадия формирования метелки). Однако мы подтвердили другое свойство крезацина, установленное ранее, - способность усиливать накопление зеленой массы $(30,35)$. В этом случае действие препарата было также связано с фазами онтогенеза (см. рис. 2). Наиболее сильный эффект обработки (увеличение массы в 1,5-2,0 раза) наблюдали на стадии скрытого роста (15-30-е сут). Поскольку в этот период рост надземной части проростков в контроле практически прекрашается, можно утверждать, что благодаря обработке такой остановки не происходило. В период активной вегетации (45-60-е сут) положительный эффект применения крезацина визуально снижался почти вдвое в сравнении с предыдущей фазой, однако реально это происходило за счет резкого усиления роста всходов в контроле после их выхода из фазы скрытого роста, тогда как эффект крезацина оставался значительным. С началом генеративной фазы (75-е сут) при закладке и формировании метелки энергетические и пластические ресурсы растений расходовались преимущественно на развитие генеративных органов. Как следствие, в эти сроки наблюдалось заметное отставание растений от контроля по высоте, однако уменьшения накопления зеленой массы не происходило. При наступлении фазы колошения (90-е сут) масса надземной части еще более снижалась. На 120-е сут масса надземной части растений, выращенных из обработанных семян, почти в 2 раза превосходила контроль, но уже не за счет зеленой массы, а в основном за счет метелки с созревшими семенами.

В результате обработки на всех этапах роста наблюдали увеличение 
массы надземной части в сравнении с контролем при неизменной высоте растений (или при отставании в росте в высоту), что приводило к положительному суммарному эффекту - габитус растений становился более крепким, чем в контроле. Благодаря этому повышалась их устойчивость к механическим повреждениям и условиям пониженной влажности, что особенно важно для всходов на стадии скрытого роста.

Необходимо особо отметить полученное в результате обработки стимулирование роста корневой системы за счет увеличения длины главного корня. Несмотря на то, что в период скрытого роста развитие корневой системы и без внешнего стимулирования идет достаточно активно и только надземная часть практически останавливается в росте, этот эффект в критический для всходов период способствует их еще более сильному укоренению, закреплению в почве и, следовательно, выживанию.

В литературе есть сведения о том, что под действием крезацина повышается содержание хлорофилла $(27,30)$. Мы не обнаружили такого изменения в листьях амаранта. При исследовании действия крезацина на световые реакции фотосинтеза мы впервые установили увеличение скорости транспорта электронов и скорости фотофосфорилирования в изолированных хлоропластах. В результате увеличивался общий энергетический пул клеток, что обеспечивало повышение ЧПФ листьев амаранта на 45-60-е сут (см. табл. 1). Такой эффект описан и для других растений (28).

Известно, что крезацин может влиять на метаболизацию соединений азота (29) и вызывает повышение содержания общего белка $(28,30)$. У растений амаранта в результате применения крезацина мы обнаружили изменения активности нитратредуктазы, содержания нитритного азота $\mathrm{N}-\mathrm{NO}_{2}$ и количества общего белка в сравнении с контролем на стадии ранней вегетации (15-45-е сут). Очевидная взаимозависимость в их изменениях отсутствовала, однако есть исследования, свидетельствующие, что между этими параметрами не всегда существует прямая зависимость (41). Определенно мы можем утверждать, что под воздействием крезацина значительно повышалось содержание полезного для человека белка в листьях, а следовательно, и пищевая ценность культуры. Колебания же в содержании нитритного азота, возможно, были связаны с активностью его использования в цепи пластических процессов, связанных с отдельными этапами этой фазы онтогенеза.

Итак, обработка семян Amaranthus caudatus L. (сортообразец K173) и Amaranthus cruenthus L. (сортообразец К185) водным раствором крезацина в концентрации $10^{-7}$ М существенно повышала их всхожесть, и значительно влияла на характеристики выращенных из них растений, в первую очередь на качество всходов. Всходы на стадии скрытого роста по массе значительно превышали контрольные, не превосходя их по высоте, благодаря чему имели более крепкий габитус, что может способствовать устойчивости к повреждающим факторам среды. Дополнительным полезным эффектом было значительное удлинение главного корня, благодаря чему всходы лучше укореняются и приобретают большую сопротивляемость ветру, недостатку влаги, сорнякам. На стадии активной вегетации в результате обработки повышалась продуктивность за счет увеличения биомассы съедобной надземной части растений. Мы не выявили видовых особенностей изменения всхожести семян и ростовых параметров растений в ответ на обработку крезационом. Обнаружено повышение питательности растений сортообразца К173 за счет увеличения в листьях содержания белка. Установлено, что описанные эффекты обусловлены стимуляци- 
ей фотохимической активности хлоропластов, сопровождающейся повышением скорости фотосинтетического фосфорилирования и увеличением энергетического пула клетки. Крезацин можно рекомендовать к использованию при культивировании листового амаранта для улучшения качества посевного материала, повышения продуктивности и питательности, а также с целью облегчения интродукции на сельскохозяйственных территориях средних широт Европы и Центральной России.

\author{
1ФГБОУ ВПО Тульский государственный \\ педагогический университет им. Л.Н. Толстого, \\ 300026 Россия, г. Тула, пр. Ленина, 125, \\ e-mail: kirillova56@inbox.ru, alisapeshkova78@mail.ru; \\ 2ФГБУН Институт фундаментальных проблем \\ биологии РАН, \\ 142290 Россия, Московская обл., г. Пущино, ул. Институтская, 2, \\ e-mail: no-reply@researchgatemail.net, cheredova@mail.ru $\square$
}

Поступила в редакцию

29 мая 2019 года

Sel'skokhozyaistvennaya biologiya [Agricultural Biology], 2020, V. 55, № 1, pp. 118-127

\title{
PROPERTIES OF CREZACIN AS A GROWTH STIMULANT OF VEGETABLE AMARANTH (Amaranthus L.)
}

\author{
L.L. Kirillova1 ${ }^{1}$, G.N. Nazarova ${ }^{2}$, A.M. Peshkova ${ }^{1}$, E.P. Ivanova ${ }^{2}$
} ${ }^{1}$ Tolstoy Tula State Pedagogical University, 125, prosp. Lenina, Tula, 300026 Russia, e-mail kirillova56@inbox.ru,
alisapeshkova78@mail.ru;
2Institute of Basic Biological Problems, 2, ul. Institutskaya, Pushchino, Moscow Province, 142290 Russia, e-mail no-
reply@researchgatemail.net, cheredova@mail.ru ( $₫$ corresponding author)

ORCID:

Kirillova L.L. orcid.org/0000-0003-3552-6590

Nazarova G.N. orcid.org/0000-0002-0244-2238

The authors declare no conflict of interests

Received May 29, 2019

Peshkova A.M. orcid.org/0000-0002-9787-6716

Ivanova E.P. orcid.org/0000-0002-2161-9035

doi: 10.15389 /agrobiology.2020.1.118eng

\section{Abstract}

Crezacin, tris(2-oxyethyl)ammonium ortho-cresoxy acetate-based adaptogen of humans and animals, is applied in Russia as a stimulant of growth and productivity of crops (wheat, oats, spinach, potatoes, etc.). In other countries, crezacin is not used for these purposes. There is no information about its use in the cultivation of food amaranth (Amaranthus L.), a source of high-quality protein and other useful substances. In this paper, we first report data on the effect of pre-sowing treatment with crezacin on seed germination, development and biometric parameters of amaranth plants during ontogenesis, and on their productivity and nutritive value. Our findings indicate the ability of crezacin to increase nitrate reductase activity, to influence the nitrite nitrogen content in the early stages of vegetation, to increase the electron transport rate ATP synthesis. The aim of the work was to assess the effect of different crezacin concentrations on seed germination, seedling quality, growth parameters, and activity of photosynthesis and nitrogen assimilation apparatus. Seeds of Amaranthus caudatus L. (sample K173) and Amaranthus cruenthus L. (sample K185) were soaked for 1 day in crezacin solutions (test) or in distilled water (control), and used in the experiments after airdrying at room temperature. In experiment $1,10^{-10}$ до $10^{-5} \mathrm{M}$ aqueous crezacin was applied to seeds then allowed for germination on wet filter paper in Petri dishes for $72 \mathrm{~h}$ at $24{ }^{\circ} \mathrm{C}$. The proportion of germinated seeds was calculated. In experiment 2, we studied the effect of crezacin on the growth and physiological and biochemical parameters of plants. Seeds were treated with $10^{-7} \mathrm{M}$ crezacin, germinated, and calibrated seedlings were transplanted into sand- filled container. Biometric parameters were measured every 15 days until harvest (120 days), productivity was estimated by the green mass increase. Chlorophyll concentration was assessed in the leaves of 45-day-old plants. The photochemical activity of isolated chloroplasts was evaluated by the rate of electron transport and photophosphorylation. From day 15 to day 45, the activity of nitrate reductase, the concentrations of N$\mathrm{NO}_{2}$ and total protein were measured in the leaves. The net photosynthesis (NP) for the period from day 45 to day 60 was calculated by A.A. Nichiporovich's method. Experiment 1 revealed a change in seed germination depending on the concentration of the preparation in both studied samples. A $10^{-8}$ concentration increased seed germination capacity by $10 \%$ compared to control $(\mathrm{P}=0.95), 10^{-7} \mathrm{M}$ had maximum stimulating effect (by $25 \%$ ), and at $10^{-5} \mathrm{M}$ the germination rate decreased by $22 \%$. Other concentrations had no significant effect. In experiment 2, in both varieties during latent 
growth stage the seedlings from the treated seeds were twice as high as the control, and the length of the main root was 1.6 times as much as in control. During later stages, the green mass of plants in the experiment exceeded the control 1.3-2.0-fold depending on the phase of ontogenesis. The treatments did not affect the height of plants. The NF value in leaves after treatment exceeded the control by $26 \%(\mathrm{P}=0.95)$. At the same time, the chlorophyll content in the leaves did not change, and the electron transport rate in chloroplasts increased by more than $30 \%$ while photophosphorylation by $60 \%$. The nitrate reductase activity in leaves on day 45 increased by almost $60 \%$, the total protein level by $20 \%$, and nitrite nitrogen amount by $16 \%(\mathrm{P}=0.95)$. These findings indicate the stimulating effect of crezacin on amaranth seeds, plant growth, photosynthesis and protein synthesis, which leads to an increase in the productivity and nutritional value of plants.

Keywords: tris(2-oxyethyl)ammonium ortho-cresoxy acetate, crezatsin, amaranth, seed germination, plant growth regulation, photophosphorylation, electron transport, protein content, nitrate reductase, productivity, nutritional value.

\section{R E F E R E N C E S}

1. Voronkov M.G., Rasulov M.M. Khimiko-farmatsevticheskii zhurnal, 2007, 41(1): 3-7 (doi: 10.30906/0023-1134-2007-41-1-3-7) (in Russ.).

2. Muromtsev G.S., Chkanikov D.I., Kulaeva O.N., Gamburg K.Z. Osnovy khimicheskoi regulyatsii rosta i produktivnosti rastenii [Fundamentals of chemical regulation of plant growth and productivity]. Moscow, 1987 (in Russ.).

3. Gosudarstvennyi katalog pestitsidov $i$ agrokhimikatov, razreshennykh $k$ primeneniyu na territorii rossiiskoi federatsii. Chast' I. Pestitsidy [The state catalog of pesticides and agrochemicals approved for use on the territory of the Russian Federation. Part I. Pesticides]. Moscow, 2015 (in Russ.).

4. Kononkov P.F., Gins V.K., Gins M.S. Amarant - perspektivnaya kul'tura XXI veka [Amaranth - a promising culture of the XXI century]. Moscow, 1999 (in Russ.).

5. Saubhik D. Amaranthus: a promising crop of future. Springer, Singapore, 2016 (doi: 10.1007/978981-10-1469-7).

6. Kraujalis P., Venskutonis P.R, Kraujalienè V., Pukalskas A. Antioxidant properties and preliminary evaluation of phytochemical composition of different anatomical parts of amaranth. Plant Foods Hum. Nutr., 2013, 68(3): 322-328 (doi: 10.1007/s11130-013-0375-8).

7. Léder I. Buckwheat, amaranth and other pseudocereal plants. In: Cultivated plants, primarily as food sources. Encyclopedia of life support systems. Vol. I. G. Fuleky (ed.). EOLSS Publications, 2009.

8. Achigan-Dako E.G., Sogbohossou O.E.D., Maundu P. Current knowledge on Amaranthus spp.: research avenues for improved nutritional value and yield in leafy amaranths in sub-Saharan Africa. Euphytica, 2014, 197(3): 303-317 (doi: 10.1007/s10681-014-1081-9).

9. Janovská D., Čepková P.H., Džunková M. Characterisation of the amaranth genetic resources in the Czech gene bank. In: Genetic diversity in plants. M. Caliskan (ed.). Publisher Technology, 2012: 457-478 (doi: 10.13140/2.1.3759.2001).

10. Pandey R.M. Biotechnological advances in amaranths species and their future outlook in crop improvement - a review. Recent Patents on DNA \& Gene Sequences, 2013, 7(3): 179-86 (doi: 10.2174/187221560703140204115514).

11. Shukla S., Pandey V., Pachauri G. Nutritional contents of different foliage cuttings of vegetable amaranth. Plant Foods Hum. Nutr., 2003, 58(3): 1-8 (doi: 10.1023/B:QUAL.0000040338.33755.b5).

12. Shukla S., Bhargava A., Chatterjee A., Srivastava J., Singh N., Singh S.P. Mineral profile and variability in vegetable amaranth (Amaranthus tricolor). Plant Foods Hum. Nutr., 2006, 61(1): 2126 (doi: 10.1007/s11130-006-0004-x).

13. Icard-Vernière Ch., Olive F., Picq Ch., Mouquet-Rivier C. Contribution of leafy vegetable sauces to dietary iron, zinc, vitamin A and energy requirements in children and their mothers in Burkina Faso. Plant Foods Hum. Nutr., 2015, 70(1): 63-70 (doi: 10.1007/s11130-014-0462-5).

14. Noumedem J.A., Mihasan M., Lacmata S.T., Stefan M., Kuiate J.R., Kuete V. Antibacterial activities of the methanol extracts of ten Cameroonian vegetables against Gram-negative multidrug-resistant bacteria. BMC Complementary and Alternative Medicine, 2013, 13: 26 (doi: 10.1186/1472-6882-13-26).

15. Negi P.S., Roy S.K. Changes in $\beta$-carotene and ascorbic acid content of fresh amaranth and fenugreek leaves during storage by low cost technique. Plant Foods Hum. Nutr., 2003, 58(3): 225-230 (doi: 10.1023/B:QUAL.0000040361.85578.b5).

16. Ortega J.A.A., Zavala A.M., Hernández M.C., Reyes J.D. Analysis of trans-fatty acids production and squalene variation during amaranth oil extraction. Open Chemistry, 2012, 10(6): 17731778 (doi: 10.2478/s11532-012-0104-4).

17. Tang Y., Tsao R. Phytochemicals in quinoa and amaranth grains and their antioxidant, antiinflammatory and potential health beneficial effects: a review. Mol. Nutr. Food Res., 2017, 61(7): 
1600767 (doi: 10.1002/mnfr.201600767).

18. Martirosyan D.M., Miroshnichenko L.A., Kulakova S.N., Pogojeva A.V., Zoloedov V.I. Amaranth oil application for coronary heart disease and hypertension. Lipids in Health and Disease, 2007, 6(1): 1-12 (doi: 10.1186/1476-511X-6-1).

19. Bavec F., Mlakar S.G. Effects of soil and climatic conditions on emergence of grain amaranths. European Journal of Agronomy, 2002, 17(2): 93-103 (doi: 10.1016/S1161-0301(01)00144-7).

20. Aufhammer W., Czuczorova D., Kaul H.P., Kruse M. Germination of grain amaranth (Amaranthus hypochondriacus $\times$ A. hybridus): effects of seed quality, temperature, light, and pesticides. $\mathrm{Eu}$ ropean Journal of Agronomy, 1998, 8(1-2): 127-135 (doi: 10.1016/S1161-0301(97)00049-X).

21. Chernov I.A. Amarant - fiziologo-biokhimicheskie osnovy introduktsii [Amaranth - physiological and biochemical basics of introduction]. Kazan', 1992 (in Russ.).

22. Bürger J., de Mol F., Gerowitt B. Influence of cropping system factors on pesticide use intensity - a multivariate analysis of on-farm data in North East Germany. European Journal of Agronomy, 2012, 40: 54-63 (doi: 10.1016/j.eja.2012.02.008).

23. Ivanova E.P., Kirillova L.L., Smolygina L.D., Serdyuk O.P. A new natural stimulator 4hydroxyphenethyl alcohol effects on amaranth seeds germination and plant productivity. Sel'skokhozyaistvennaya biologiya [Agricultural Biology], 2011, 5: 118-122 (in Russ.).

24. Ivanova E.P., Kirillova L.L., Nazarova G.N. Gibbersib effects on amaranth seeds germination and plant productivity. Sel'skokhozyaistvennaya biologiya [Agricultural Biology], 2014, 1: 91-97 (doi: 10.15389/agrobiology.2014.1.91rus) (in Russ.).

25. Kirillova L.L., Nazarova G.N., Ivanova E.P. para-Aminobenzoic acid stimulats seed germination, plant growth, development, photosynthesis and nitrogen assimilation in the amaranth (Amaranthus L.). Sel'skokhozyaistvennaya biologiya [Agricultural Biology], 2016, 51(5): 688-695 (doi: 10.15389/agrobiology.2016.5.688eng).

26. Voronkov M.G., Dolmaa G., Tserenpil Sh., Ugtakhbayar O., Chimidtsogzol A. Stimulation of barley seed germination by micromolar aqueous solutions of silatrane and cresacin. Dokl. Biol. Sci., 2005, 404: 367-369.

27. Bairambekov Sh.B., Korinets V.V., Valeeva Z.B., Dubrovin N.K, Bicherev V.A., Korneva O.G., Polyakova E.V. Shlyakhov V.A., Kufaev A.A., Dubin R.I., Gerasimov P.V. Tekhnologiya proizvodstva kartofelya $v$ astrakhanskoi oblasti [Potato production technology in the Astrakhan region]. Astrakhan', 2007 (in Russ.).

28. Polovinkin V.G., Isaichev V.A., Provalova E.V. Izvestiya Nizhnevolzhskogo agrouniversitetskogo kompleksa: nauka $i$ vysshee professional'noe obrazovanie, 2013, 1(29): 95-101 (in Russ.).

29. Isaichev V.A., Andreev N.N., Kaspirovskii A.V. Vestnik Ul'yanovskoi gosudarstvennoi sel'skokhozyaistvennoi akademii, 2013, 3(23): 14-19 (in Russ.).

30. Stepanov A.F., Milashenko A.V., Prokhorova N.A. Omskii nauchnyi vestnik, 2012, 2(114): 179184 (in Russ.).

31. Kunavin G.A., Kuznetsov N.N. Agrarnyi vestnik Urala, 2013, 4(110): 53-55 (in Russ.).

32. Wintermans J.F.G.M., De Mots A. Spectrophotometric characteristics of chlorophyll a and b and their pheophytins in ethanol. Biochimica et Biophysica Acta (BBA) - Biophysics including Photosynthesis, 1965, 109(2): 448-453 (doi: 10.1016/0926-6585(65)90170-6).

33. West K.R., Wiskich J.T. Photosynthetic control by isolated pea chloroplasts. Biochem. J., 1968, 109(4): 527-532.

34. Izava S., Good N.E. Hill reaction rates and chloroplasts fragment size. Biochimica et Biophysica Acta (BBA) - Biophysics including Photosynthesis, 1965, 109(2): 372-381.

35. Tumerman L.A., Fedorovich I.B. V knige: Bioenergetika i biologicheskaya spektrofotometriya [Bioenergy and biological spectrophotometry]. Moscow, 1967: 35-40 (in Russ.).

36. Hageman R.H., Reed A.J. Nitrate reductase from higher plants. Methods in Enzymology, 1980, 69: 270-280 (doi: 10.1016/S0076-6879(80)69026-0).

37. Bradford M.M. Rapid and sensitive gram quantities of protein utilizing the principle of protein-dye binding. Analytical Biochemistry, 1976, 72(1-2): 248-254 (doi: 10.1016/0003-2697(76)90527-3).

38. Nichiporovich A.A. Fotosinteticheskaya deyatel'nost' rastenii kak osnova ikh produktivnosti $v$ biosfere $i$ zemledelii [Photosynthetic activity of plants as the basis of their productivity in the biosphere and agriculture]. Moscow, 1988 (in Russ.).

39. Plant hormones: biosynthesis, signal transduction, action! P.J. Davies (ed.). Kluwer Academic Publishers, London, 2004.

40. Bektas Y., Eulgem T. Synthetic plant defense elicitors. Front. Plant Sci., 2015, 26(5): 804 (doi: 10.3389/fpls.2014.00804).

41. Cheeseman J.M., Tankou S.K. Nitrate reductase and growth of Arabidopsis thaliana in solution culture. Plant and Soil, 2005, 266(1-2): 143-154 (doi: 10.1007/s11104-005-0947-1). 